\title{
Birth, life and death of the Pannonian Lake
}

\author{
Miklós Kázmér \\ Department of Palaeontology, Eötvös University, Kun Béla tér 2, H-1083 Budapest, Hungary
}

(Received January 30, 1989; revised and accepted January 25, 1990)

\begin{abstract}
Kázmér, M., 1990. Birth, life and death of the Pannonian Lake. Palaeogeogr., Palaeoclimatol., Palaeoecol., 79: $171-188$.

The Miocene-Pliocene Pannonian Lake formed in an extensional basin system behind the compressional arc of the Carpathians. Its size and depth were comparable to those of the Caspian Sea. Subsidence began in Middle Miocene times, forming deep, pelagic basins, separated by reef-bearing ridges. Clastic influx filled the marginal basins during Middle Miocene time. Prograding deltas dissected the lake and completed the infilling of the basin system by the end of the Pliocene. Basin plain, prodelta, delta front, delta plain, beach, fluviatile, and marsh environments can be recognized.

Terminal Miocene uplift of the Carpathians isolated the Pannonian region from the rest of Paratethys. The subsequent decrease of salinity resulted in the evolution of an endemic, freshwater mollusc fauna. Rich nutrient influx from rivers supported high organic productivity (dinoflagellates, diatoms, nannoplankton, foraminifers, ostracods, etc.), yielding organic-rich sediments. Preservation of organic matter was helped by a stratified water column and oxygen deficient bottom conditions. Deep burial, continuing subsidence, and high geothermal flux due to an extremely thin crust, led to the formation of commercially exploitable oil and gas accumulations.

Shallow lacustrine zones of basin margins provided suitable environments for a rich Congeria-Melanopsis mollusc fauna. Wave action on beaches produced commercially exploitable pure quartz sand deposits. Taxodium and Alnus forests flourished around the lake producing enormous lignite deposits. Besides a rich land snail and mammal fauna, prehominids lived in the forests. There was a warm, temperate climate, with probably frostfree winters. Basaltic volcanoes overlooked the landscape, and maars hosted minor lakes with rich algal flora forming oil shale.

The catchment area included most of the Carpathians and parts of the Alps and Dinarides. The positive water balance resulted in a supposed overflow in the southern margin, supplying exotic fauna to the South Carpathian and Dacian basins of the Eastern Paratethys. The Pannonian Lake was completely filled by the end of Pliocene. Recent lakes in the Carpathian Basin are not descendants of it
\end{abstract}

\section{Introduction}

A series of smaller or greater depressions are associated with the Alpine chains along the southern margin of the European plate. The largest of them is the Pannonian Basin, surrounded by the Carpathians, Alps, and Dinarides (Fig.1). It hosted the Pannonian Lake for a period of ca 10 million years, during Late Miocene and Pliocene times.

The complete life-time of the Pannonian Lake lasted from about $12 \mathrm{Ma}$, when it became separated from the huge brackish water body along the northern margin of the Alpine chains, known as the Paratethys, until 2.4 Ma (the Pliocene-Pleistocene boundary), by which time it was completely filled in by sediments. Today the sediments of the former lake cover an area of about $250,000 \mathrm{~km}^{2}$, comparable in size to the present Caspian Sea $\left(370,000 \mathrm{~km}^{2}\right)$.

Our story begins when the lithospheric plates of the Carpathian-Pannonian region assembled to form their present pattern (Balla, 1987), causing the uplift of the Carpathian arc and the isolation of the Pannonian Lake (Steininger and Rögl, 1985). Compression and thrusting in the Carpathians lasted until the Late Miocene or Pliocene in different parts of the arc (Jiřiček, 1979), overriding the subducting European plate. Differences in compression along the mountain range produced associated back-arc basins, as in other regions 


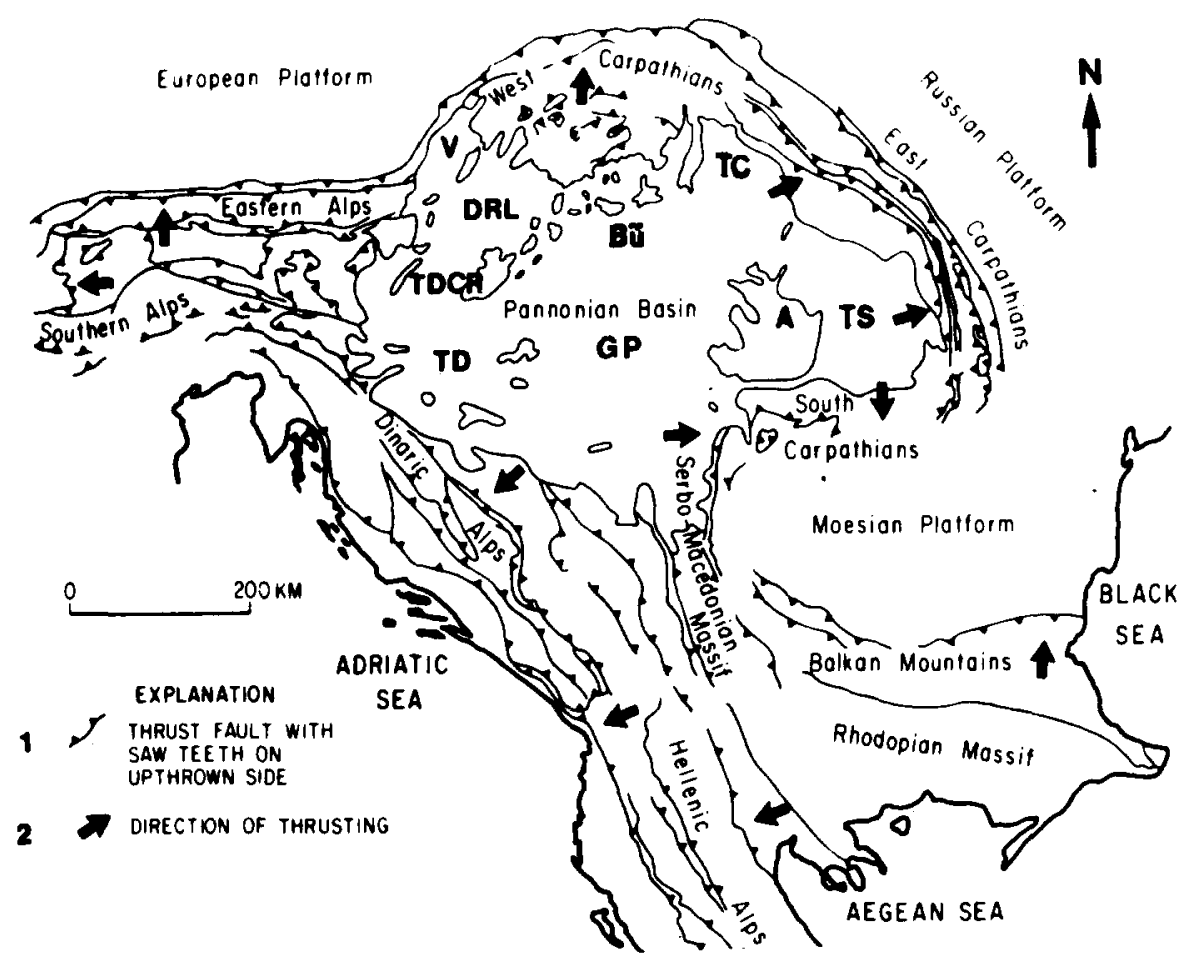

Fig.1. The Pannonian Basin system is seated among the Alps, Carpathians, and Dinarides. The largest, central basin is the Great Plain $(G P)$, while the Vienna Basin (V), Danube-Rába Lowland $(D R L)$, SW-Transdanubian Basin $(T D)$, Transylvanian Basin (TS), and Transcarpathian Basin (TC) are adjoining minor basins. These are separated by mountains, like Transdanubian Central Range $(T D C R)$, Apuseni Mountains $(A)$, or Bükk (Bü) (after Mattick et al., 1985).

of the Alpine chain (Horváth and Berckhemer, 1982).

The basement of the Neogene-Quaternary Pannonian Basin is made up mostly of Mesozoic and Palaeozoic rocks; both the lithology and the tectonic style can be correlated with the Mesozoic nappe systems in the internal zones of the adjacent mountains (Kázmér, 1986).

The name of the basin, and of the lake, is derived from the Pannonian province, part of the ancient Roman Empire from 11 A.D. until the 4th century. When World War I terminated a millennium of Hungarian domination, the region became divided among six countries, where geological literature is published in ten languages (Hungarian, German, Czech and Slovakian, Ukrainian and Russian, Romanian, Serbian, Croatian, and Slovenian). This linguistical caleidoscope hinders mutual understanding, and each other's results are frequently overlooked. Probably the present paper is not exempt from it.
Most of the Pannonian Basin lies in Hungary, where an ambitious hydrocarbon exploration and production programme (including several thousand boreholes) has been running for over 50 years. The present paper is based on published Hungarian data, with necessary additions from the neighbouring countries.

\section{Basin evolution}

\section{Tectonics}

The continental crust of the Pannonian Basin was about $36 \mathrm{~km}$ thick in Middle Miocene time. How did it reach its actual $24-27 \mathrm{~km}$ thickness?

Subcrustal thinning of the lithosphere began in the Ottnangian (for regional chronostratigraphic units see Fig.2), providing a general but moderate subsidence in the central region. Its effect is shown by the area with 0 to $2 \mathrm{~km}$ sediment thickness in Fig.3. 

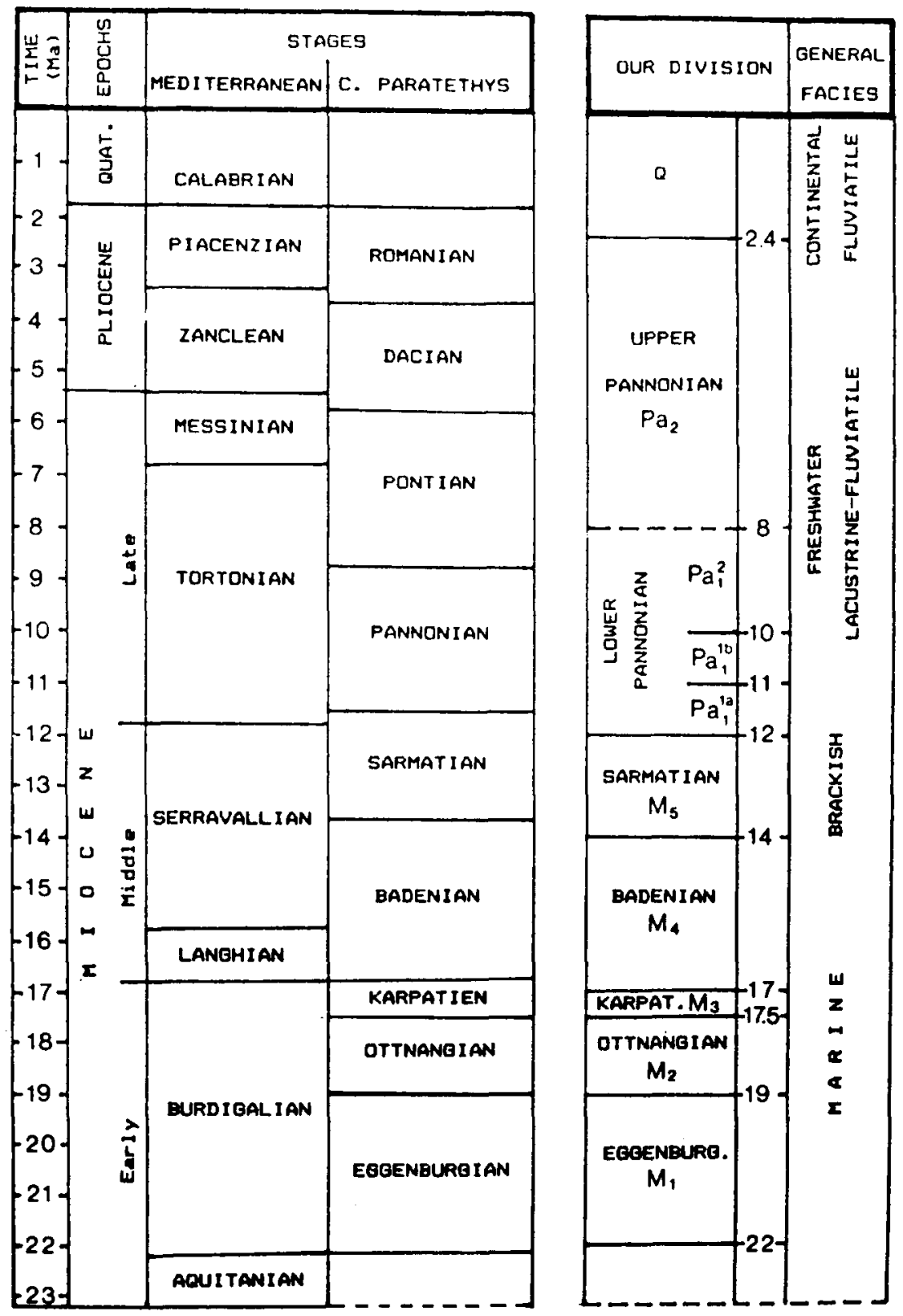

Fig.2. Regional chronostratigraphic units of the Mediterranean and the Central Paratethys (= Pannonian Basin). The right column displays the classical stratigraphic units applied by the Hungarian oil industry (Horváth, 1986).

In Badenian time a superposed $\mathrm{N}-\mathrm{S}$ compression produced a complex stress pattern (Bergerat et al., 1984), with a major, E-W tensional component. It established several minor, deep basins (Fig.3), arranged in a clear-cut extensional basin system (Fig.4). The strain pattern was dominated by SW-NE, mostly left-lateral strike-slip faults, and associated normal faults, bordering the deep basins. Seismic profiling reveals listric normal faults, represented as synthetic and antithetic growth faults rotating the enclosed blocks (Fig.5). Extension along the Kadarkút profile (locality $A$ on Fig.4), for example, was about $50 \%$ for the fault-affected basins, almost zero for the neigh- 


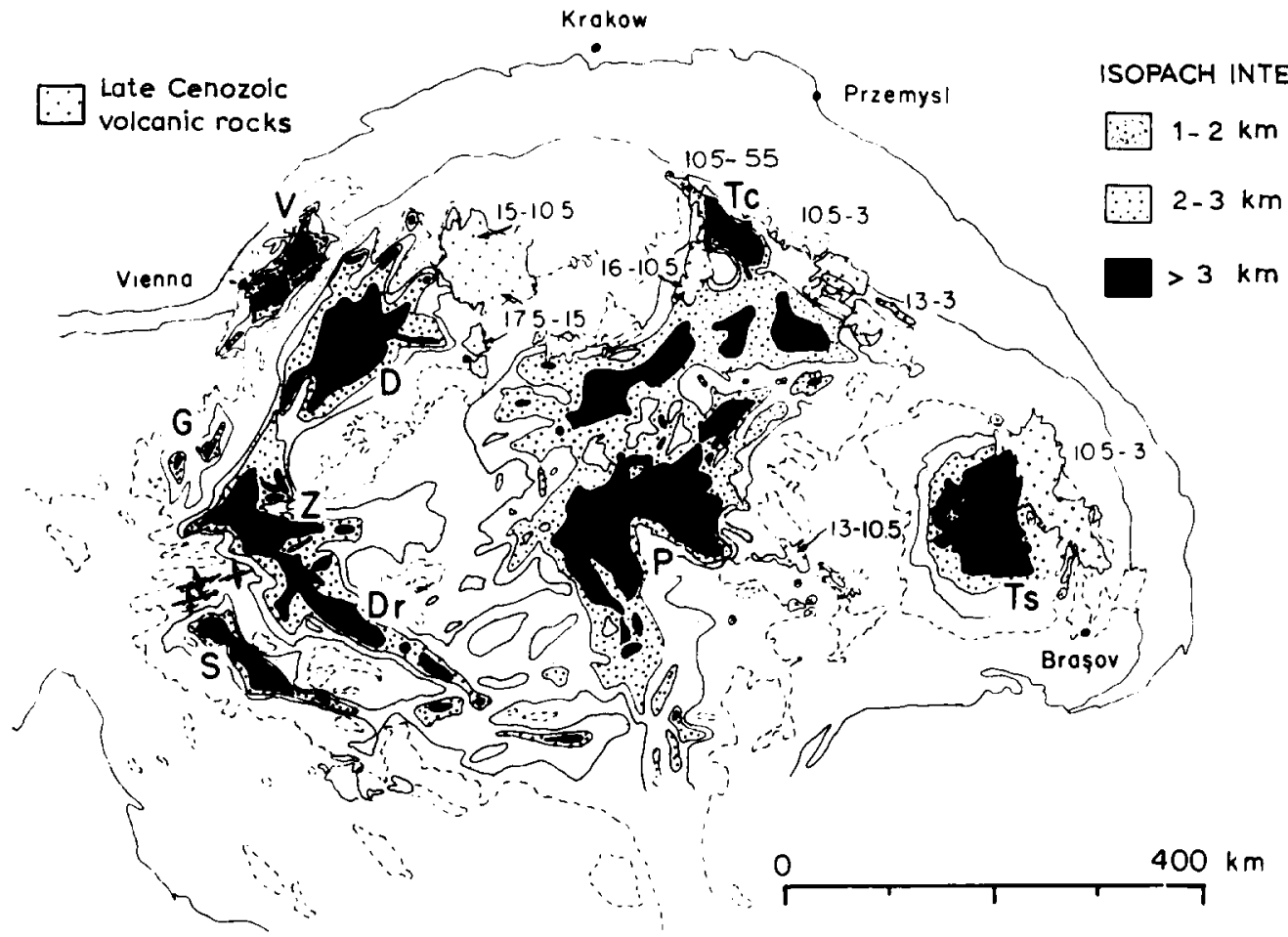

Fig.3. Thickness map of Miocene to Quaternary sediments shows depocenters of the Pannonian Basin system. Approximate ages ot contemporary intermediate to acidic igneous rocks are also shown (Póka, 1982). Fold axis symbols show location and trend of some of the Sava folds affecting Pliocene sediments. Basins: $V=$ Vienna, $D=$ Danube, $G=\mathrm{Graz}, Z=\mathrm{Zala}, S=\mathrm{Sava}, D r=\mathrm{Drava}, P=\mathrm{Pannonian}$ (s.str.), $T c=$ Transcarpathian, $T s=$ Transylvanian. Dashed lines show regions of pre-Neogene outcrops (Royden et al., 1983).

bouring basement blocks, totalling $20 \%$ for the profile.

The basin subsidence can be explained by the combined effects of isostatic compensation for crustal thinning and the subsequent cooling and thermal contraction of the crust and upper mantle (Royden et al., 1983).

\section{Volcanic activity}

There was extensive volcanic activity along the eastern margin of the Pannonian Lake from 10 to $3 \mathrm{Ma}$ (Late Miocene-Pliocene) (Fig.3). The products are andesitic to rhyolitic ignimbrites, pyroclastics and lesser volumes of lava. Volcanism was related to the subduction of the European plate below the Eastern Carpathians (Balla, 1981).

Basaltic volcanoes were scattered in the Pannonian Basin. Their eruptions occurred from 11 to $1 \mathrm{Ma}$, mostly on land, more rarely below the lake (Balogh et al., 1986). Their origin is less well known than that of the andesites, but it may have been connected with the extension of the Pannonian Basin.

\section{Stratigraphy (Table 1)}

The classical subdivision of Pannonian sediments at lake margins is based on benthonic bivalves and gastropods, and is supported by lithological and facies studies. Their environmental sensitivity and endemism make the correlations inside and outside the lake somewhat questionable (Korpás-Hódi, 1983). Since formations and ecozones were hardly applicable in the deep basins, alternative lithological subdivisions, supported by well-log data were established by the hydrocarbon industry, later corroborated and interpreted by seismic stratigraphy. Correlation within the Pannonian Basin seems to be best attained by extensive seismic profiling. Planktonic stratigraphy, based on dinoflagellates, and palaeomagnet- 

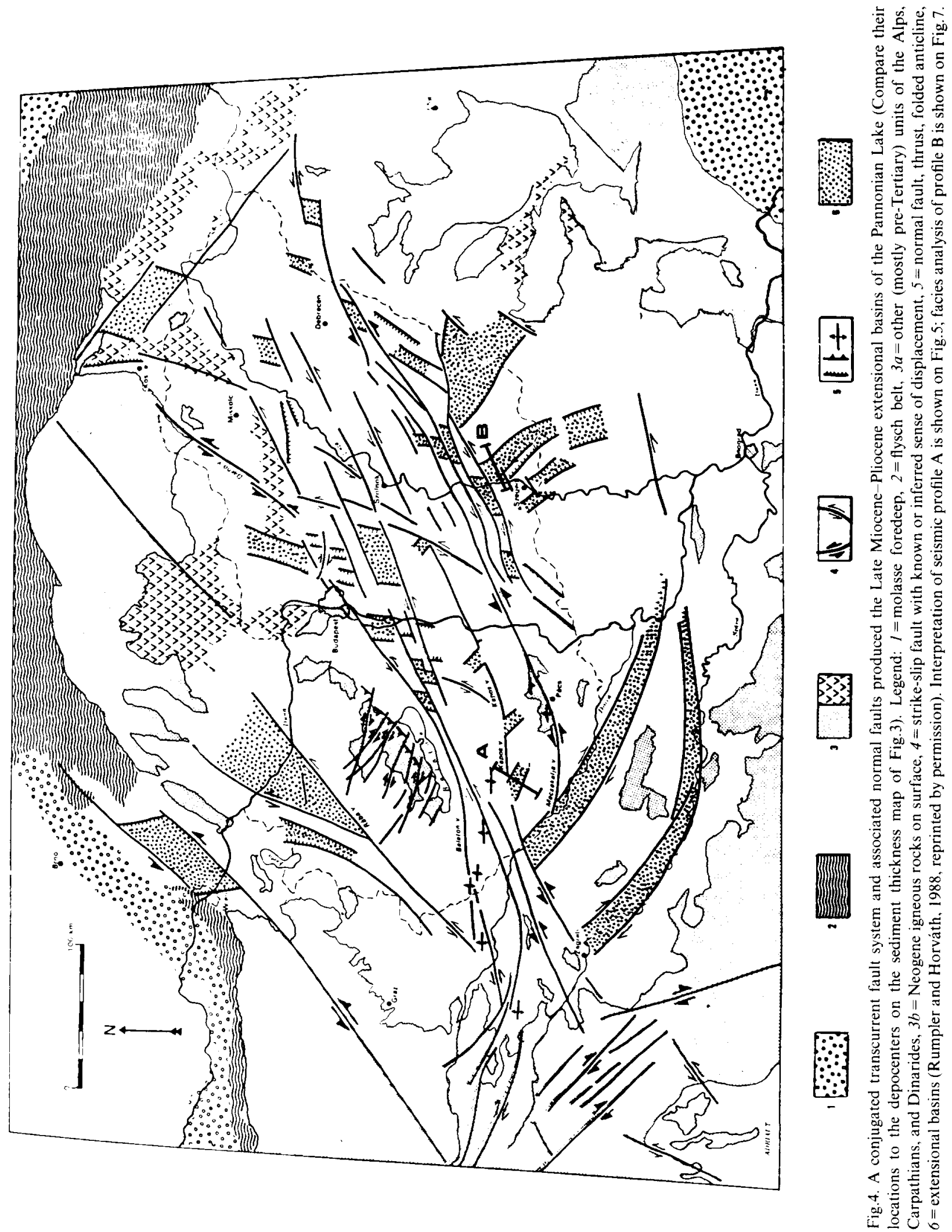


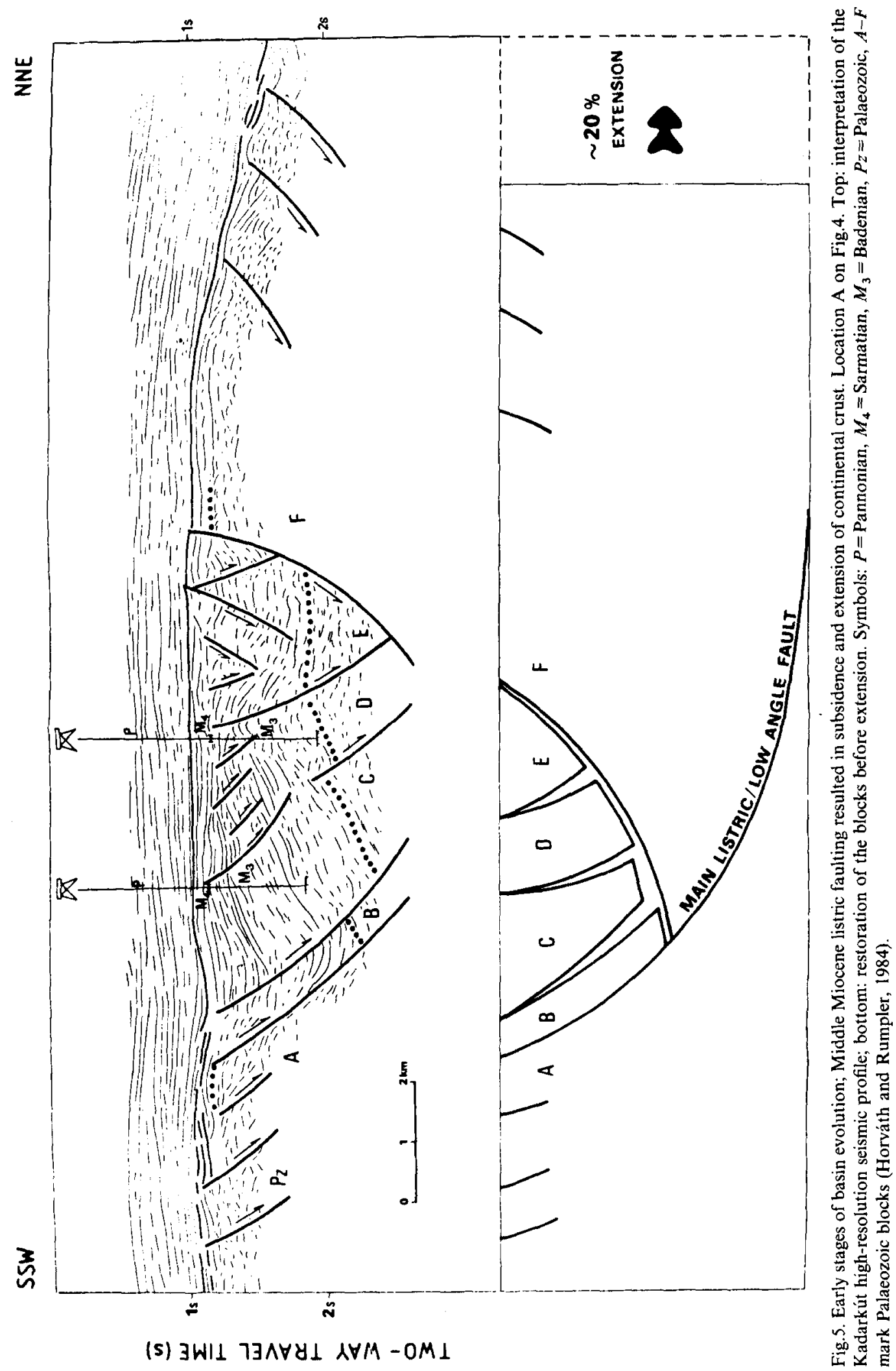


TABLE 1

Selected papers on the stratigraphy of the Pannonian Basin

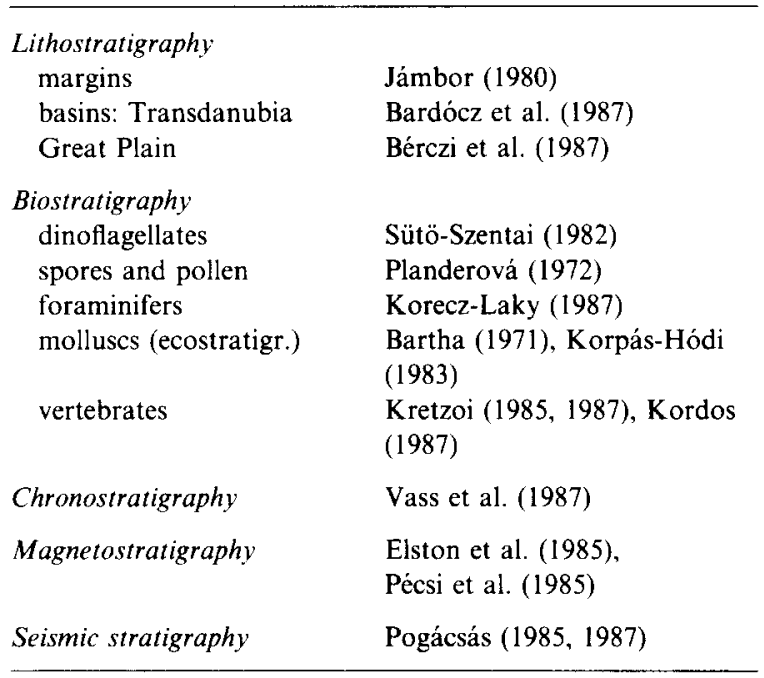

ism associated with seismic stratigraphy are promising new methods to overcome the difficulties.

Stages of the Central Paratethys and their correlation with Mediterranean chronostratigraphic units are shown in Fig.2. However, to understand the terminology of classical studies and present usage in hydrocarbon industry, an alternative column illustrates the notions "Lower" and "Upper" Pannonian.

\section{Sedimentology}

Formation of the Pannonian Basin began in the Middle Miocene (Badenian). Marine environments prevailed at this time, with neritic carbonate deposition (Leithakalk) on submarine highs and bathyal pelitic sedimentation in the depressions. Sedimentation did not keep pace with rapid subsidence, hence locally deep water conditions (up to thousand meters) persisted. Clastic supply derived from the uplifting Alps and mostly from the Carpathians was trapped in the marginal Vienna and Transcarpathian Basins. After their filling up by the end of Middle Miocene, the central and later the southern sub-basins began to receive sediments (Figs.3 and 6). The direction of sediment supply was from the north, west, and east towards the centre of the basin (Pogácsás and Révész, 1987).
Facies

The Makó trough (locality $B$ on Fig.4) hosts the thickest Neogene-Quaternary infill (more than $7 \mathrm{~km}$ ) in the Pannonian Basin. Borehole profiles across the trough (Fig.7) clearly indicate that infilling followed subsidence in time (Bérczi and Phillips, 1985). The Middle Miocene (Badenian) thin basal sediments (1) are redeposited conglomerates alternating with marl beds, indicating deposition in a rapidly subsiding basin. The deep basin facies (2) consists of dark, laminated silty marls, without coarse clastic intercalations, deposited in a deep, oxygen-deficient basin. The prodelta facies (3) begins with distal turbidites, the number and thickness of marl intercalations decreasing upwards. The top of this facies contains abundant slump structures, predominantly in sandstones. No bioturbation has been observed in facies 1-3.

The delta front-delta slope facies (4) is made up of inclined sandstone strata with dips up to $20^{\circ}$, and abundant soft sediment deformation structures. In the upper two thirds of the facies there are abundant traces of bioturbation. Facies 4 is the first to occur not only in the deep basin, but also on the neighbouring highs. It indicates that the prograding delta covered both former basins and highs, filling the Pannonian Lake almost completely. Large scale foresets, recognized on highresolution seismic profiles, indicate that lake depth had reached $700-900 \mathrm{~m}$ at the time of the delta progradation (Pogácsás and Révész, 1987).

The delta plain facies above consists of horizontal bedded sandstone and marl, with occasional lignite intercalations.

The facies model of Bérczi and Phillips (1985) (Fig.8) displays dissected bottom topography, with bathyal sedimentation between the highs, and a prograding delta hiding all topographic features while completely filling the basin.

The composite diagram of lake depth changes (based on seismic stratigraphy and interpretation of depositional environments) (Fig.9) shows that an initially starved basin, reaching $1 \mathrm{~km}$ in depth was later filled by sediments.

While the deep basins were characterized by a relatively simple facies assemblage, a wide variety of environments were established at the margins 

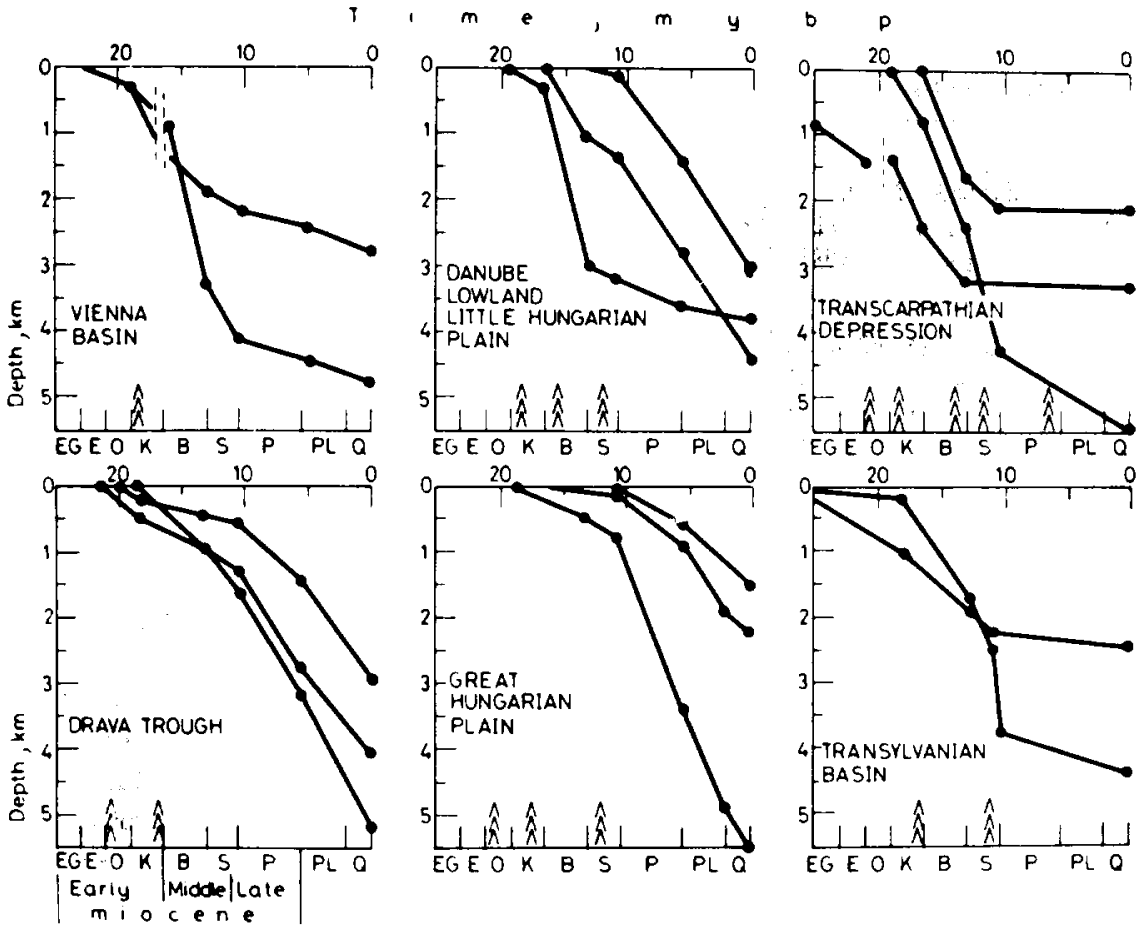

Fig.6. Infilling of the Middle Miocene extensional basins proceeded from external to internal depressions. The main filling event occurred between 15 and $10 \mathrm{Ma}$ in the Vienna, Transcarpathian, and partly Transylvanian Basins. Most of the internal basins (Danube, Drava, Great Plain) have been filled up subsequently. Sedimentation versus time diagrams (stacked triangles indicate the time of calc-alkaline volcanism) (Horváth and Berckhemer, 1982).

(Jámbor, 1987). Besides the common shallow lacustrine, marsh, and fluviatile facies of sand, clay, and coal measures, variegated clay, etc., lagoons and ponds hosted special environments with deposition of freshwater limestone, pure white sand, cemented by silica, or diatomite and oil shale.

\section{Palaeolimnology}

\section{Salinity}

Pannonian Lake waters experienced two significant changes. The first occurred at about $14 \mathrm{Ma}$ ago, at the Badenian/Sarmatian boundary, when normal marine conditions changed to brackish, more or less simultaneously throughout the whole Paratethys. It was caused by the final separation of Paratethys from the Mediterranean, and from the Indopacific region. The uplift of the Carpathians 12 Ma ago established the Pannonian Lake, separ- ating it from the rest of Paratethys (Rögl and Steininger, 1984). While continuous sedimentary columns do not show any lithological change in this interval, the species diversity of the fauna abruptly decreased (Dank and Jámbor, 1987). During the Sarmatian, ostracod faunas indicate minor changes of salinity within a range of 15-25\%. Then the lowermost Pannonian indicates a sudden decrease to $8-15 \%$, followed by a more or less freshwater environment. The upper part of the Pannonian in this sequence indicates a brackish water environment with 8-15\% salinity. Percentage values are provided by comparisons with modern ostracod assemblages in the Caspian and Black Seas (Korecz, 1985).

Chemical analysis of connate water from artesian wells in the Pannonian Basin display a general decrease of salinity with time (Fig.10). Waters from $1-3 \mathrm{~km}$ depth yielded saline water of sodiumchloridic composition $(5-15 \mathrm{~g} / 1 \mathrm{NaCl})$, while sediments from minor depths yielded freshwater 


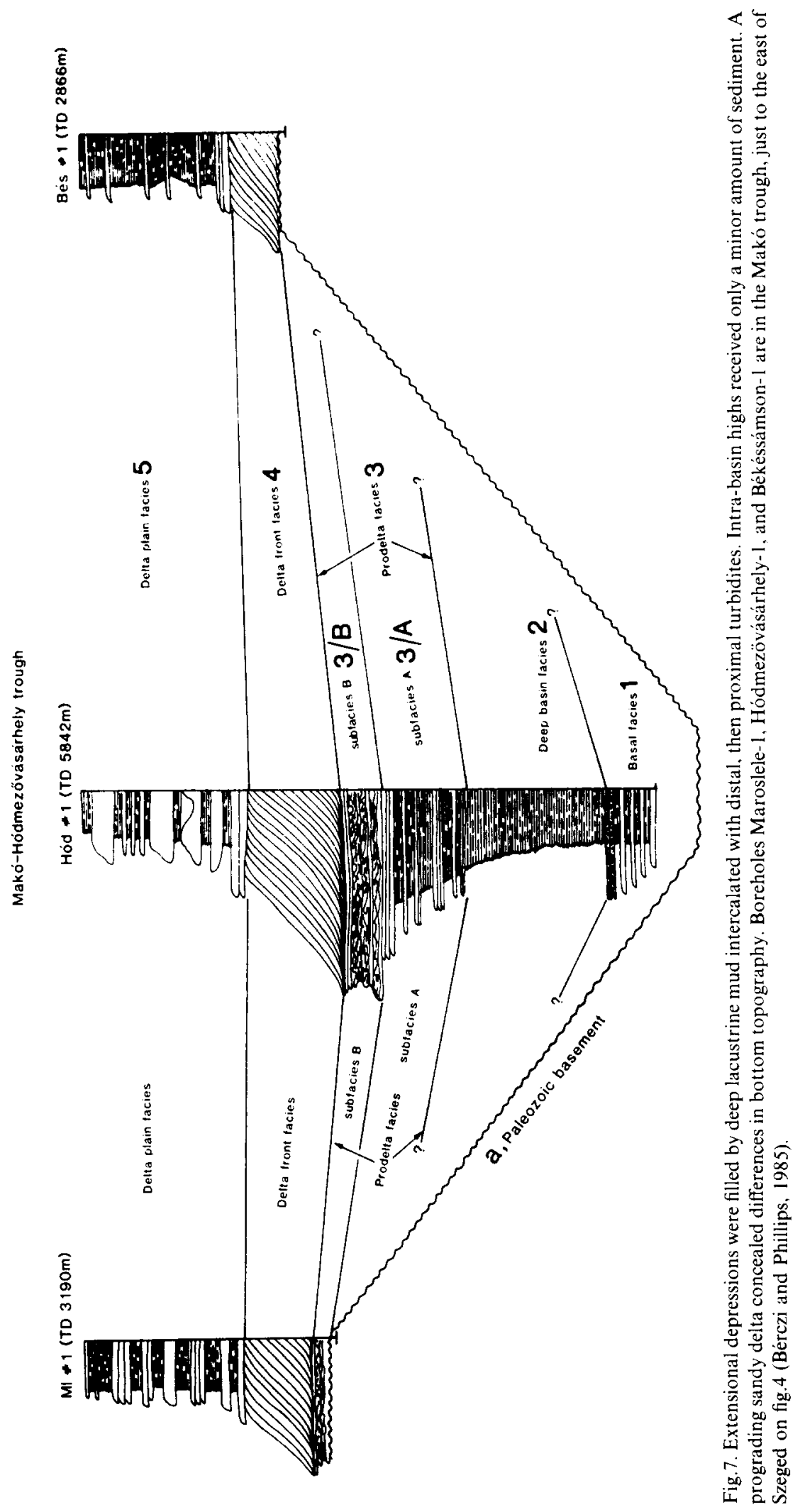




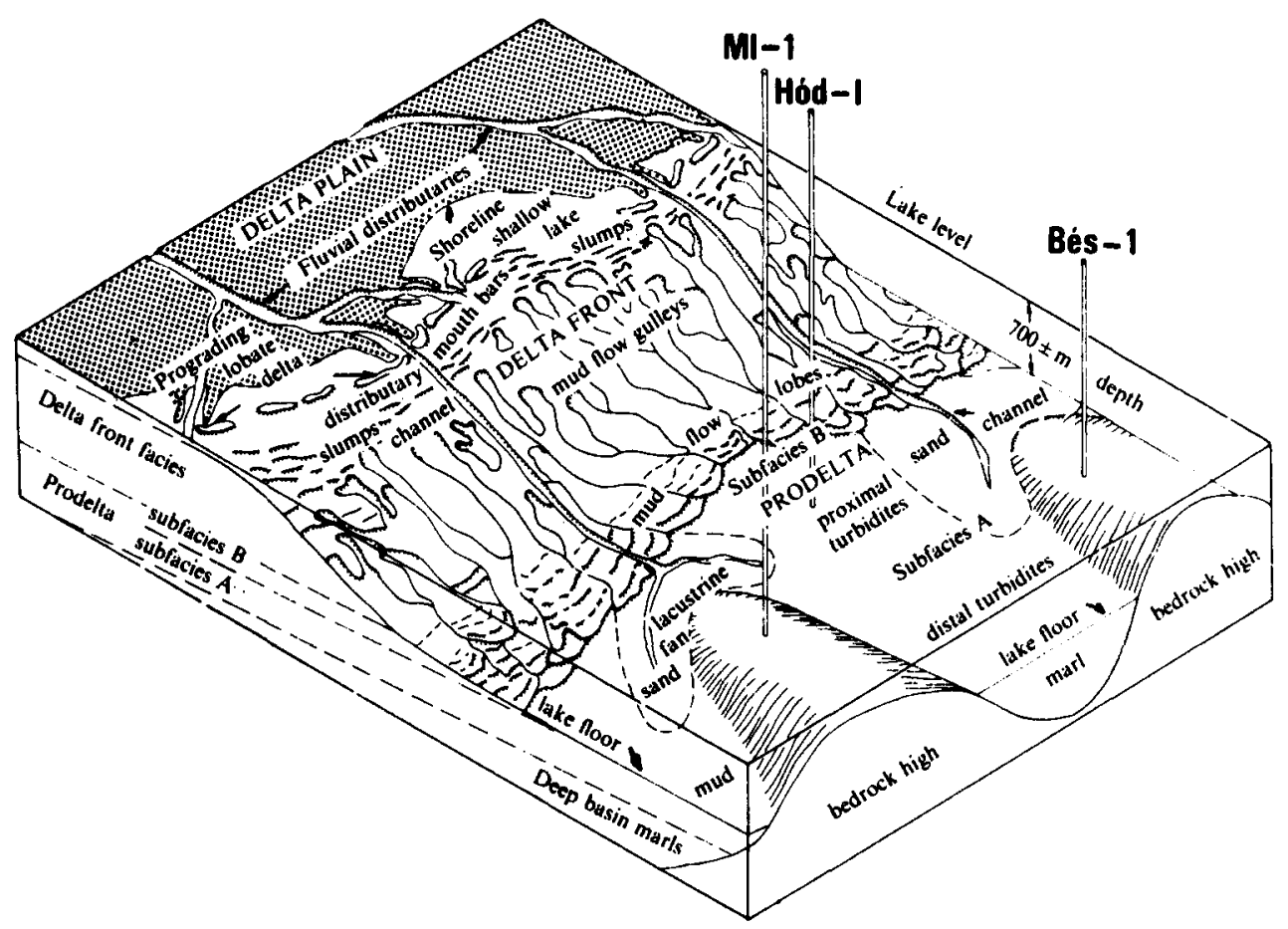

Fig.8. Facies model of the Upper Miocene-Pliocene basin fill of the Makó trough in the Pannonian Basin (Bérczi and Phillips, 1985). Progradation of the delta resulted in the vertical assemblage of facies observed in the boreholes on Fig.6.

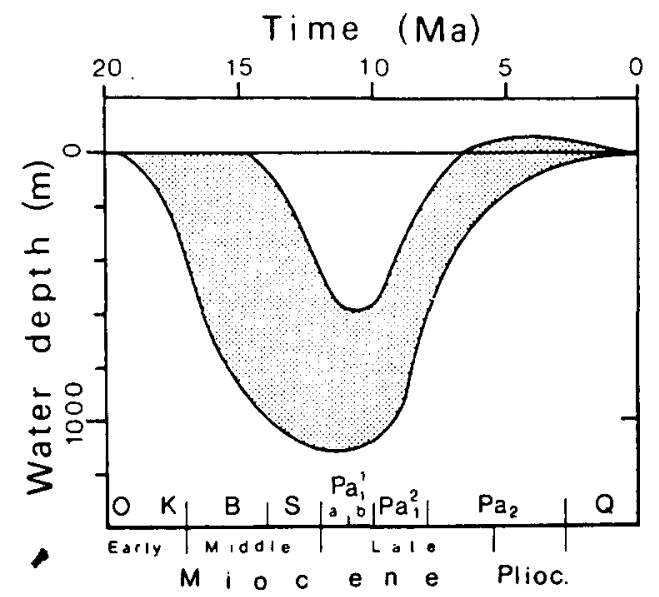

Fig.9. Depth changes of the Pannonian Lake within the central extensional basins in time. After $10 \mathrm{Ma}$ subsidence continued (see Fig.5), while increased clastic supply filled the basins. Uplift and erosion was negligible (Horváth et al., 1988, reprinted by permission).

of sodium-bicarbonate composition $\quad(0.02 \mathrm{~g} / 1$ $\mathrm{NaCl}$ ) (Korim, 1966; Kleb, 1971). While vertical change reflects the commonly observed increase in salinity with depth typical of many sedimentary basins, the older sediments yield more saline waters than the younger ones from the same depth interval. (Fig.10).

\section{Stratification}

Deep basin and prodelta facies lack bioturbation, while delta front and slope facies bear abundant traces of infaunal activity (Bérczi and Phillips, 1985). This absence, together with associated framboidal pyrite in basin facies (Hámor, 1988) is taken as evidence for a stratified water column. Stratification might have been produced by abundant, year-long freshwater supply (indicating large rivers), or the absence of seasonal overturn of the water body in the more than $700 \mathrm{~m}$ deep lake. The Pannonian Lake contained several local, closed basins. These were thermally and chemically stratified (meromictic). Seasonal or continuous high organic productivity by phytoplankton and bacteria in the epilimnion resulted in the accumulation of organic-rich calcareous sediment below an anoxic hypolimnion. 


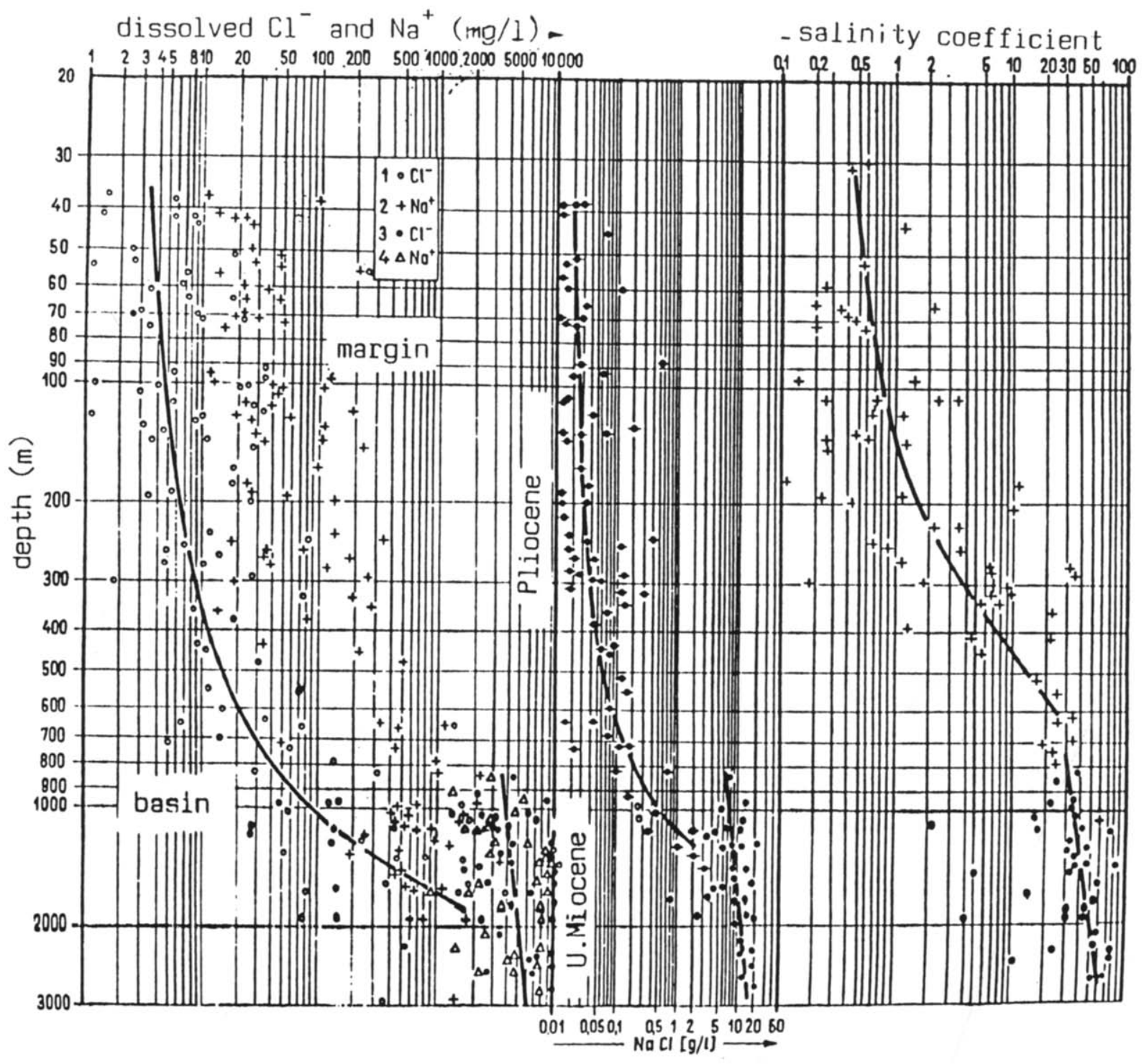

Fig.10. Increase of salinity with depth in the connate waters of the Pannonian basin fill indicate a shift from Late Miocene brackish to Late Pliocene freshwater composition. The right curve indicates changes in the salinity coefficient of Stadnikoff (1958): equivalent Na divided by equivalent $\mathrm{Ca}$ (Kleb, 1971).

\section{Water balance}

The sudden decrease of salinity at the Sarmatian/Pannonian boundary indicates high fresh-water input and positive water balance. The rivers carried their sediment load (identified by micromineralogy) mostly from the Carpathians in $\mathrm{N}-\mathrm{S}$ direction (Elek, 1987). Inflow was greater than evaporation, therefore an (intermittent) outflow existed through the Southern Carpathians (the Iron Gate) (Kojumdgieva, 1983) until ca.7 Ma, supplying characteristic Pannonian CongeriaMelanopsis mollusc fauna to the Dacian Basin (Steininger and Rögl, 1985; Papaianopol and Olteanu, 1979). The outflow may have ceased from 4-5 Ma onwards (Lubenescu, 1981).

\section{The lake biota (Table 2)}

All faunal associations in the Pannonian Lake were different from and show significant decrease in diversity compared to the Sarmatian ones. 
TABLE 2

Selected papers on the fossil biota of the Pannonian Lake and its surroundings

\begin{tabular}{ll}
\hline diatoms & Hajós (1985) \\
nannoplankton & Bóna and Gál (1985) \\
dinoflagellates & Sütö-Szentai (1985) \\
spores and pollen & Nagy (1985), Nagy and \\
& Planderová (1985) \\
plants & $\begin{array}{l}\text { Knobloch (1985), Givulescu } \\
\text { (1986) }\end{array}$ \\
foraminifers & Korecz-Laky (1985) \\
thecamoebans & Schreiber et al. (1985) \\
gastropods and bivalves & Bartha (1971), Papp (1985) \\
land snails & Lueger (1985) \\
ostracods & Jiříček (1985), Krstić (1985) \\
annelids & Jámbor and Radócz (1970) \\
fishes & Koch (1904), Brzobohatý and \\
& Panǎ (1985) \\
mammals & Rabeder (1985) \\
prehominids & Kordos (1987) \\
ichnofossils & Jámbor (1980, 1987) \\
\hline
\end{tabular}

Diatoms (Hajós, 1985) lived near the margins of the Pannonian Lake, and are found in marl, diatomite, clay, tuffite, and sand beds. Deep basin sequences are barren of diatoms, probably due to diagenetic dissolution of the tests. Most of the 117 species are planktonic and epiphytic, besides a few benthonic ones. Nearshore, warm water species predominated. Most species preferred brackish or freshwater, there were only a few euryhaline species. There was also a large amount of variable, large-size, heavily ornamented, endemic species. Other siliceous fossils are: silicoflagellates, ebridians, unicellular flagellates, Chrysomonadales cysts, and Phytolitharia.

Calcareous nannoplankton (Bóna and Gál, 1985) is represented by 17 species, five of them being endemic. These occur in clay and silt, in borehole profiles near the lake margins. Most of them are tiny specimens, not yet systematically described. Although these occur abundantly in a few layers, probably do not make significant contribution to the sediment.

Dinoflagellates (Sütö-Szentai, 1985) are suitable for the correlation of margin and basin sequences. The 28 species help to define 6 biozones, based on occurrences determined by water temperature and composition. Other chitinous organisms are: scolecodonts, foraminifers, and freshwater green algae.

Two species of the siliceous rhizopod genus Silicoplacentina (Thecamoeba) (Schreiber et al., 1985) occur in Lower Pannonian sediments of Hungary and Austria. These are probably indicators of deep (lacustrine) environments.

Besides the rich, redeposited Sarmatian foraminifer faunas, 5-7 species of endemic, agglutinated foraminifers occur in lowest Pannonian sediments (Korecz-Laky, 1985).

The Pannonian Lake is best known for its bivalves and gastropods (Bartha, 1971; Papp, 1985). The bivalve Congeria (Fig.11), the gastropodsTheodoxus and Melanopsis are remnants of a more diverse Sarmatian fauna. The isolation of the lake produced a wide variety of endemic forms, like the bivalves Limnocardium, Dreissena, peculiar gastropods: the extremely evolute Valenciennesia and the straight Orygoceras. Marginal environments are characterized by Congeria and Melanopsis, while basin sediments are rich in Limnocardium. The gastropod Viviparus is abundant in fluviatile and shallow lacustrine environments.

More than 90 species of ostracods (Jiřiček, 1985, Krstić, 1984) are known from lakeshore and deep basin environments of the Pannonian Basin. While poor for correlation purposes, they are highly suitable for environmental analysis (Korecz, 1985).

The fishes are rarely whole specimens (Koch, 1904), but mostly otoliths and teeth of teleostei (Brzobohatý and Pană, 1985). The fauna is poorly described. Mostly brackish water species are known, freshwater ones being subordinate (probably due to greater chance of preservation in earlier, deep lacustrine environments). Both benthonic and nektonic, carnivorous and herbivorous types occur among the 41 species known. The fauna seems to be marine, surviving the "salinity crisis" at the Sarmatian/Pannonian boundary, associated with some endemic Pannonian species.

\section{Climate and environments of adjacent land areas}

A mixed mesophytic forest containing about hundred species dominated the landscape (Thenius, 1982). Algae and other aquatic plants abounded in ponds. Galleries of marsh and swamp 


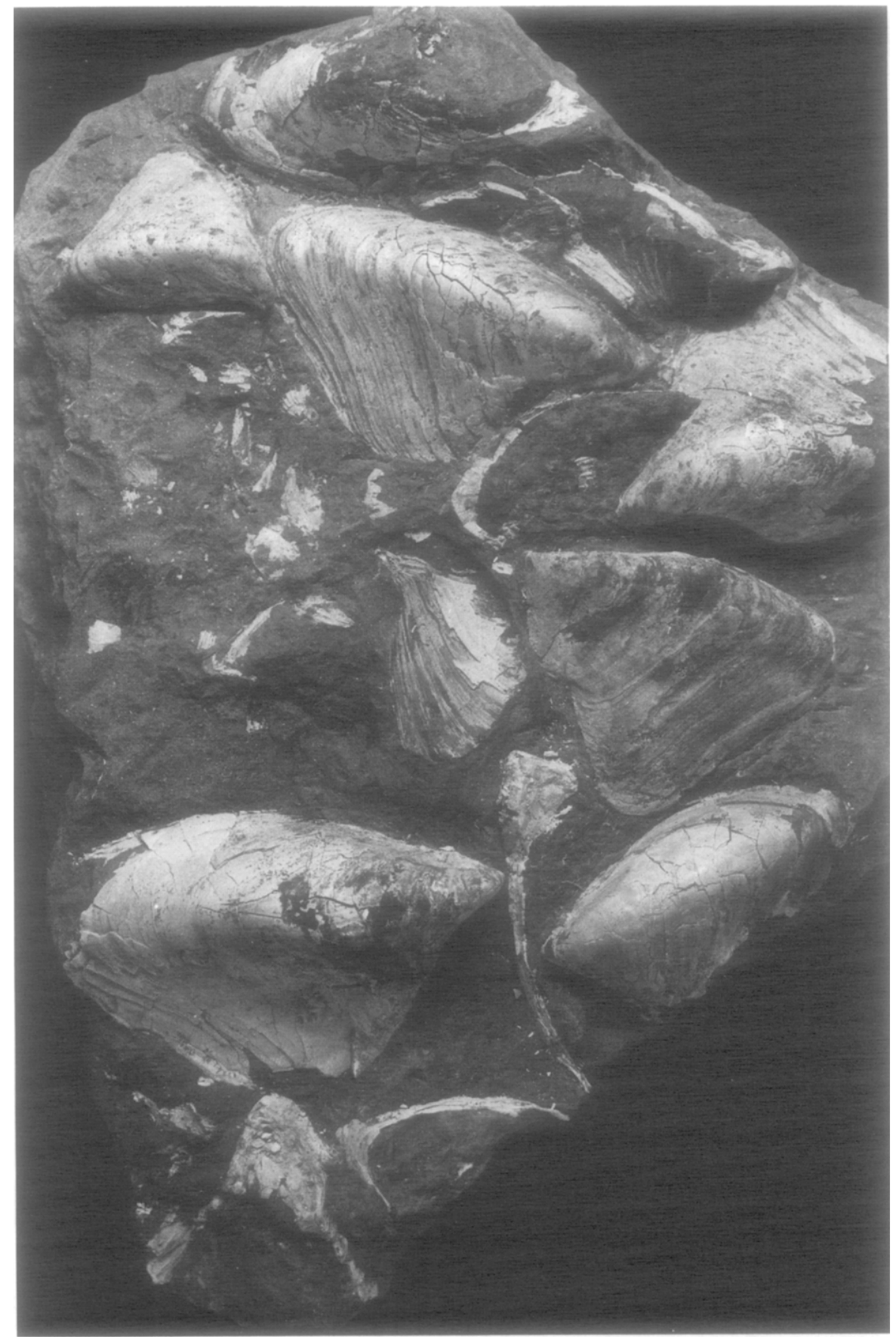

Fig.11. Congeria bivalves are the most frequent fossils of the Pannonian Lake (collection of the Department of Palaeontology, Eötvös University, Budapest; photo: Ágoston Nagy).

forests (Taxodium, Alnus) stretched along the lake shore and along watercourses. Besides closed forests, open woodlands with mixed deciduous trees and grasses occurred, too. Coniferous forests formed a significant part of the flora, not only at higher elevations, but also at the lakeshore 
(Magyar, 1988). Subtropical elements were present, but no palms.

Characteristic forms of the mammal fauna (Rabeder, 1985) were rhinos, chalicotheriums, tapirs, forest antelopes, dinotheriums, mastodons, and frequent hipparions, and last but not least, ancestral prehominids (Rudapithecus) (Kordos, 1987)).

The mixed mesophytic forests indicate a warm, temperate climate with mild, probably frostfree winters. Mean annual temperature was above $13^{\circ} \mathrm{C}$, while $22^{\circ} \mathrm{C}$ was the average temperature of the warmest month. Mean precipitation was above $1000 \mathrm{~mm} / \mathrm{yr}$, without a markedly dry season. Regions with comparable modern vegetation and climate are found in China $\left(25-35^{\circ} \mathrm{N}\right.$ lat., $200-750 \mathrm{~m}$ above sea level) and Japan $\left(30-32^{\circ} \mathrm{N}\right.$ lat., $0-500 \mathrm{~m}$ a.s.1.). Climatic differences have been recognized between northern and southern parts of the Pannonian region, subtropical elements occurring in the latter only. Part of the plains in the middle part of the Pannonian Basin may have had different vegetation with more open woodlands, where numerous animals of today's African savannas lived (Kretzoi et al., 1976; Thenius, 1982; Nagy and Planderová, 1985; Givulescu, 1986).

\section{Palaeogeography (Figs.12 and 13)}

About $14 \mathrm{Ma}$ ago (Badenian) seaways existed from the Carpathian-Pannonian region through Anatolia to the Indopacific realm. Orogenic movements from the Badenian onwards disconnected the Paratethys basins from the world ocean and from each other, too. Rivers reduced the salinity of the water, followed by decreased diversity and increasing endemism of the fauna. From $12 \mathrm{Ma}$ onwards only three major basins remained: the Pannonian, the Black Sea, and the Caspian Basins, without significant connections between them. While the Black Sea and Caspian Basins have maintained the enormous water body in them (because marginal depressions trapped the sediment load of the rivers), the Pannonian Lake was filled by the end of Pliocene, despite continuing subsidence (Rögl and Steininger, 1984; Kojumdgieva, 1983). The Recent shallow lakes (Balaton, Fertö, Neusiedler See) - being younger than 20,000 years - bear no connections to the Pannonian Lake.

\section{Resources (Table 3)}

The most important mineral resources of the Pannonian Basin are water, hydrocarbons and

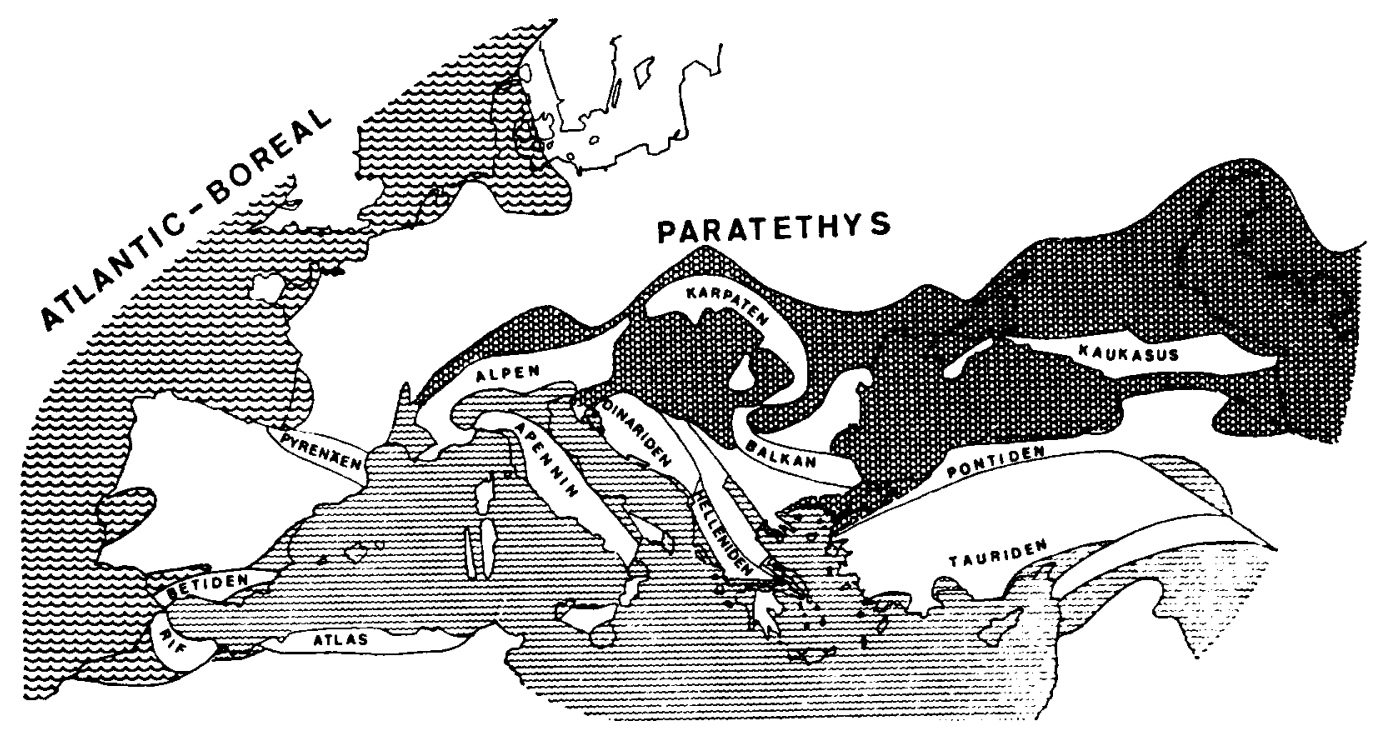

MEDITERRANE TETHYS

Fig.12. Marine bioprovinces in the (Middle) Miocene of Europe (Rögl and Steininger, 1983). The inland sea among the Alps, Carpathians, and Dinarides is the site of extensional basin formation. 


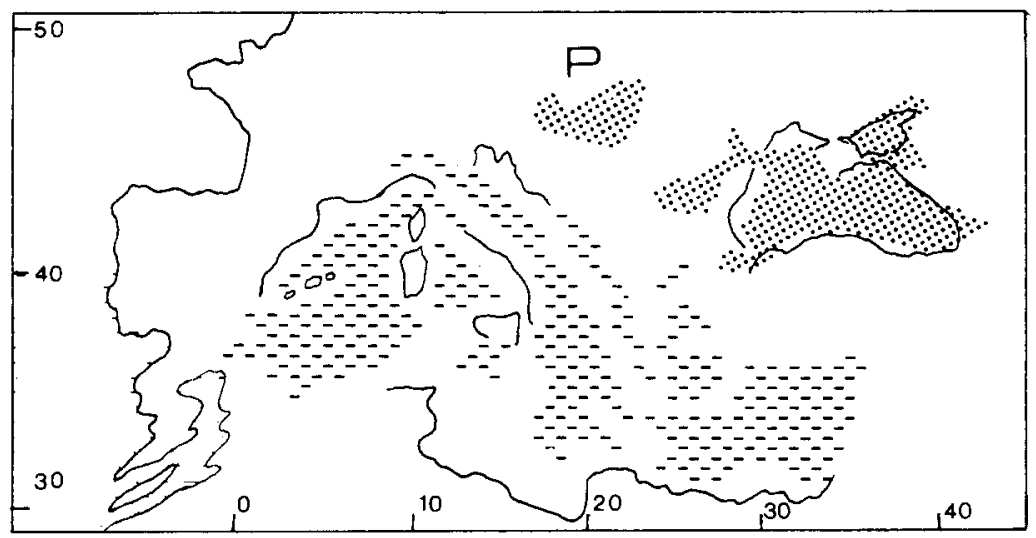

Fig. 13. Latest Miocene palaeogeography. The Pannonian Lake $(P)$ is the westernmost lake of the disintegrated Paratethys (dotted). Meanwhile the Mediterranean was hit by the Messinian salinity crisis (dashed lines) (after Steininger and Rögl, 1985, modified).

TABLE III

Natural resources of the Pannonian Basin (ore deposits excluded)

$\begin{array}{ll}\begin{array}{l}\text { hydrocarbons } \\ \text { thermal water, freshwater }\end{array} & \begin{array}{l}\text { Dank (1985) } \\ \text { Erdélyi (1978), Rónai } \\ (1978)\end{array} \\ \text { mineral waters } & \text { Dobos (1985) } \\ \text { lignite } & \text { Radócz (1985) } \\ \text { oil shale } & \text { Solti (1985a) } \\ \text { diatomite } & \text { Jámbor (1971) } \\ \text { bentonite } & \text { Solti (1985b) } \\ \text { quartz sand } & \text { Thamó-Bozsó (1985), } \\ & \text { Bihari (1987) }\end{array}$

feldspar sand

clay, sand, gravel, flagstone

lignite. Thermal waters, from 20 to $100^{\circ} \mathrm{C}$ in temperature are tapped by more than 20,000 artesian wells for communal water supply, balneotherapy and heating.

Oil fields are located around the deep basins in the Vienna, Zala, Dráva Basins, in the Great Plain and the Transylvanian Basin. Organic geochemistry of hydrocarbons (distribution of $n$-alkanes in capillary gas chromatographic spectra) (Sajgó, 1980; Sajgó et al., 1988) indicates that crude oil is derived mostly from organic matter of planktonic algae $(n=17,18,19)$, with minor additions from coniferous trees $(n=27,31,33)$. The source rocks are mostly Lower Pannonian marls, deposited in oxygen deficient environments; the traps are mostly in the interbedded and overlying sand- stones. The passive upwelling of hot asthenosphere during extension of the crust produced elevated thermal gradients (Dövényi et al., 1983), which helped the sediments of the Pannonian Lake to reach the oil-generation window between 1800-2500 m (Jámbor et al., 1987).

Oil shale occurs mostly in the craters of basaltic volcanoes (maars); it accumulated in strongly eutrophic small lakes. It is quarried as a natural fertilizer.

Bentonite is a weathering product of rhyolite tuff and basalt tuff.

Pure quartz sand and siliceous sandstone were formed in embayments of the lake, under joint influence of wave activity (sorting) and aggressive groundwater (dissolution of non-silica minerals). These are quarried for glass factories.

\section{Acknowledgements}

The author has greatly benefited from the comments of B. Géczy, F. Horváth, M. Monostori (Eötvös University, Budapest), C. Sajgó (Geochemical Research Laboratory, Budapest), and $\mathrm{M}$. R. Talbot (University of Bergen). Their help is sincerely acknowledged herein.

\section{References}

Balla, Z., 1981. Neogene volcanism of the Carpatho-Pannonian region. Earth Evol. Sci., 1: 240-248.

Balla, Z., 1987. Tertiary palaeomagnetic data for the CarpathoPannonian region in the light of Miocene rotation kinematics. Tectonophysics, 139: 67-98. 
Balogh, K., Árva-Sós, E., Pécskay, Z., Ravasz-Baranyai, L., 1986. K/Ar dating of post-Sarmatian alkali basaltic rocks in Hungary. Acta Mineral. Petrogr., 28: 75-93.

Bardócz, B., Bíró, E., Dank, V., Mészáros, L., Németh, G. and Tormássy, I., 1987. Pannonien s. str.-Bildungen der Transdanubische Beckengebiete. Ann. Inst. Geol. Publ. Hung., 69: 149-177.

Bartha, F., 1971. A magyarországi pannon biosztratrigráfiai vizsgálata. In: F. Bartha, B. Kleb, L. Körössy, É. Szabóné Kilényi, P. Szatmári, M. Széles, G. Szénás and K. Tóth, (Editors), A magyarországi pannonkori képzödmények kutatásai. Akadémiai Kiadó, Budapest, pp. 9-172.

Bérczi, I. and Phillips, R. L., 1985. Processes and depositional environments within Neogene deltaic-lacustrine sediments, Pannonian basin, Southeast Hungary. Geophys. Trans., 31: 55-74.

Bérczi, I., Dank, V., Gajdos, I., Pap, S., Révész, I., Szentgyörgyi, K. and Völgyi, L., 1987. Ablagerungen der Kunság-Stufe (Pannonien s. str.) auf der Grossen Ungarischen Tiefebene. Ann. Inst. Geol. Publ. Hung., 69: 179-211.

Bergerat, F., Geyssant, J. and Lepvrier, C., 1984. Etude de la fracturation dans le bassin Pannonien: Méchanismes et étapes de sa création. Ann. Soc. Géol. Nord, 103: 265-272.

Bihari, G., 1987. Palaeogeogrpahy of the formation of industrial sand deposits in Hungary. Ann. Inst. Geol. Publ. Hung., 70: 531-535.

Bóna, J. Gál, M., 1985. Kalkiges nannoplankton im Pannonien Ungarns. In: A. Papp, Á. Jámbor, F. F. Steininger, (Editors), Chronostratigraphie und Neostratotypen, Miozän der Zentralen Paratethys VII, $\mathrm{M}_{6}$ Pannonien (Slavonien und Serbien). Akadémiai Kiadó, Budapest, pp. 482-515.

Brzobohatý, R. and Panǎ, I., 1985. Die Fischfauna des Pannonien. In: A. Papp, Á. Jámbor, and F. F. Steininger, (Editors), Chronostratigraphie und Neostratotypen, Miozän der Zentralen Paratethys VII, $\mathrm{M}_{6}$ Pannonien (Slavonien und Serbien). Akadémiai Kiadó, Budapest, pp. 426-439.

Dank, V., 1985. Hydrocarbon exploration in Hungary. In: J. Hála (Editor), Neogene Mineral Resources in the Carpathian Basin. Historical Studies on Their Utilization. Hung. Geol. Surv., Budapest, pp. 107-213.

Dank, V. and Jámbor, Á., 1987. Allgemeine geologische Merkmale der Ablagerungen des Pannonien s. str. (KunságStufe) in Ungarn. Ann. Inst. Geol. Publ. Hung. 69: 9-25.

Dobos, I., 1985. Exploration of subsurface waters in the Neogene basins. In: J. Hála (Editor), Neogene Mineral Resources in the Carpathian Basin. Historical Studies on Their Utilization. Hung. Geol. Surv., Budapest, pp. 531-555.

Dövényi, P., Horváth, F., Liebe, P., Gálfi, J. and Erki, I., 1983. Geothermal conditions of Hungary. Geophys. Trans., 29: 3-114.

Elek, I., 1987. Alföldi kutatófúrások mikromineralógiai feldolgozásából levonható következtetések. Annu. Rep. Hung. Geol. Inst., 1985: 127-135 (in Hungarian, with English abstract).

Elston, D. P., Hámor, G., Jámbor, Á., Lantos, M. and Rónai, P., 1985. Magnetostratigraphy of Neogene strata penetrated in two deep core holes in the Pannonian basin: preliminary results. Geophys. Trans., 31: 75-88.

Erdélyi, M., 1978. Hydrodynamics of the Hungarian Basin. In:
A. Rónai (Editor), Hydrogeology of Great Sedimentary Basins. Ann. Inst. Geol. Publ. Hung., 59: 146-162.

Givulescu, R., 1986. Bref aperçu sur les fossiles du bassin Néogène de Borod, com. Bihor, Roumanie. Rev. Paléobiol., 5: $249-251$.

Hajós, M., 1985. Diatomeen des Pannonien in Ungarn. In: A. Papp, Á. Jámbor and F. F. Steininger (Editors), Chronostratigraphie und Neostratotypen, Miozän der Zentralen Paratethys VII, $\mathrm{M}_{6}$ Pannonien (Slavonien und Serbien). Akadémiai Kiadó, Budapest, pp. 534-585.

Hámor, T., 1988. Genetics and facies analysis of sedimentary pyrites in Upper Pannonian deposits intersected by borehole Tiszapalkonya I. Annu. Rep. Hung. Geol. Inst. 1986: 413-464 (In Hungarian, with English abstract).

Horváth, F., 1986. A Pannon-medence kialakulásának geofizikai modellje. Geophysical model of the formation of the Pannonian Basin. Thesis. Dep. Geophys., Eötvös Univ., Budapest, 148 pp. (unpublished).

Horváth, F. and Berckhemer, H., 1982. Mediterranean backarc basins. In: H. Berckhemer and K. Hsü (Editors), AlpineMediterranean Geodynamics (Geodynamics Series, 7). Am. Geophys. Union, Washington, D.C., pp. 141-173.

Horváth, F. and Rumpler, J., 1984. The Pannonian basement: extension and subsidence of an Alpine orogene. Acta Geol. Hung., 27: 229-235.

Horváth, F., Dövényi, P., Szalay, Á. and Royden, L., 1988. Subsidence, thermal and maturation history of the Great Hungarian Plain. Am. Assoc. Pet. Geol. Mem., 45: 355-373.

Jámbor, Á., 1980. Pannonian in the Transdanubian Central Mountains. Ann. Inst. Geol. Publ. Hung., 62, 259 pp.

Jámbor, Á., 1987. Die Lebensspurenfauna der pannonischen (s.1.) Bildungen in Ungarn. Ann. Inst. Geol. Publ. Hung., 69: 423-433.

Jámbor, Á. and Radócz, G., 1970. Pectinarien aus dem oberen Neogen von Ungarn. Földt. Közl., 100: 360-371.

Jámbor, Á., Balázs, E., Balogh, K., Bérczi, I., Bóna, J., Horváth, F., Gajdos, I., Geiger, J., Hajós, M., Kordos, L., Korecz, A., Korecz-Laky, I., Korpás-Hódi, M., Köváry, J., Mészáros, L., Nagy, E., Németh, G., Nusszer, A., Pap, S., Pogácsás, G., Révész, I., Rumpler, J., Sütö-Szentai, Á., Szalay, Á., Szentgyörgyi, K., Széles, M. and Völgyi, L., 1987. General characteristics of Pannonian s.l. deposits in Hungary. Ann. Inst. Geol. Publ. Hung., 70: 155-167.

Jiřičck, R., 1979. Tektogenetický v'voj karpatského oblouku bêhem oligocénu a neogénu. In: $M$. Mahel (Editor), Tektonické profily Západných Karpát. Geologický Ústav Dionýza Stúra, Bratislava, pp. 203-214 (in Slovakian, with English abstract).

Jiřiček, R., 1985. die Ostracoden des Pannonien. In: A. Papp, Á. Jámbor and F. F. Steininger, (Editors), Chronostratographie und Neostratotypen, Miozän der Zentralen Paratethys VII, $\mathbf{M}_{6}$ Pannonien (Slavonien und Serbien). Akadémiai Kiadó, Budapest, pp. 378-425.

Kázmér, M., 1986. Tectonic units of Hungary: Their boundaries and stratigraphy (A bibliographic guide). Ann. Univ. Sci. Budapest., Sect. Geol., 26: 45-120.

Kleb, B., 1971. A pannon emeletbeli kiédesedés üledékföldtani és geokémiai vizsgálata. In: F. Bartha, B. Kleb, L. Körössy, É. Szabóné Kilényi, P. Szatmári, M. Széles, G. Szénás and K. 
Tóth (Editors), A magyarországi pannonkori képżodmények kutatásai. Akadémiai Kiadó, Budapest, pp. 173-197.

Knobloch, E., 1985. Die Floren des Pannonien im Wiener Bekcen und in der Donauebene. In: A. Papp, Á. Jámbor and F. F. Steininger (Editors), Chronostratographie und Neostratotypen. Miozän der Zentralen Paratethys VII, $\mathrm{M}_{6}$ Pannonien (Slavonien und Serbien). Akadémiai Kiadó, Budapest. pp. 616-631.

Koch, A., 1904. Die fossilen Fische des Beocsiner Cementmergels. Ann. Mus. Nat. Hung., 2: 1-72.

Kojumdgieva, E., 1983. Palaeogeographic environment during the desiccation of the Black Sea. Palaeogeogr., Palaeoclimatol., Palaeoecol., 43: 195-204.

Kordos, L.. 1987a. Neogene vertebrate biostratigraphy in Hungary. Ann. Inst. Geol. Publ. Hung., 70: 393-396.

Kordos, L., 1987b. Description and reconstruction of the skull of Rudapithecus hungaricus Kretzoi (Mammalia). Ann. Hist. Nat. Mus. Natl. Hung., 79: 77-88.

Korecz, A.. 1985. Die Ostracodenfauna des Zsámbéker Beckens. In: A. Papp, Á. Jámbor and F. F. Steininger (Editors), Chronostratigraphie und Neostratotypen, Miozän der Zentralen Paratethys VII, Mo Pannonien (Slavonien und Serbien). Akadémiai Kiadó, Budapest, pp. 173-177.

Korecz-Laky, I., 1985. Foraminiferen im Pannonien Ungarns. In: A. Papp, Á. Jámbor and F. F. Steininger (Editors). Chronostratigraphie und Neostratotypen, Miozän der Zentralen Paratethys VII, $M_{6}$ Pannonien (Slavonien und Serbien). Akadémiai Kiadó, Budapest, pp. 265-269

Korecz-Laky, I., 1987. Studies on Foraminifera from the Miocene of Hungary. Ann. Rep. Hung. Geol. Inst., 1985: $467-480$.

Korim, K., 1966. The connate waters of the Hungarian Neogene. Acta Geol. Acad. Sci. Hung., 10: 407-426.

Korpás-Hódi, M.. 1983. Palaeoecology and biostratigraphy of the Pannonian Mollusca fauna in the northern foreland of the Transdanubian Central Range. Ann. Inst. Geol. Publ. Hung., 66, $163 \mathrm{pp}$.

Kretzoi, M., 1985. Sketch of the biochronology of the Late Cenozoic in Central Europe. In: M. Kretzoi and M. Pécsi (Editors), Problems of the Neogene and Quaternary. Akadémiai Kiadó, Budapest, pp. 3-20.

Kretzoi, M., 1987. Terrestrische Biochronologie/Stratigraphie des Karpatenbeckens in Pannonien (s.1.). Ann. Inst. Geol. Publ. Hung., 69: 393-422.

Kretzoi, M., Krolopp. E., Lörincz, H. and Pálfalvy, I., 1976. Flora, Fauna und stratigraphische Lage der unterpannonischen Prehominiden-Fundstelle von Rudabánya (NO-Ungarn). Annu. Rep. Hung. Geol. Inst., 1974: 365-394.

Krstić, N., 1985. Ostracoden im Pannonien der Umgebung von Belgrad. In: A. Papp, Á. Jámbor and F. F. Steininger (Editors), Chronostratigraphie und Neostratotypen, Miozän der Zentralen Paratethys VII, $\mathbf{M}_{6}$ Pannonien (Slavonien und Serbien). Akadémiai Kiadó, Budapest, pp. 103-143.

Lubenescu. V., 1981. Quelques considérations concernant les formes a viviparidés dans le Bassin Dacique. Rév. Roum. Géol. Géophys. Géogr. Géol., 25: 155-157.

Lueger, J. P., 1985. Die Landschnecken des Pannonien. In: A. Papp, Á. Jámbor and F. F. Steininger (Editors), Chronostratigraphie und Neostratotypen, Miozän der Zentralen Para- tethys VII, $\mathbf{M}_{6}$ Pannonien (Slavonien und Serbien). Akadémiai Kiadó, Budapest, pp. 340-377.

Magyar, I., 1988. Molluse fauna and flora of the Pannonian quartz sandstone at Mindszentkálla. Hungary. Ann. Univ. Sci. Budapest., Sect. Geol., 28: 209-222.

Mattick, R. E., Rumpler, J. and Phillips, R. L., 1985. Seismic stratigraphy of the Pannonian Basin in Southeastern Hungary. Geol. Trans., 31: 13-54.

Nagy, E., 1985. Sporomorphs of the Neogene in Hungary. Geol. Hung., ser. Palaeontol., 47: $1-471$.

Nagy, E. and Planderová, É., 1985. Palynologische Auswertung der Floren des Pannonien. In: A. Papp. Á. Jämbor and F. F. Steininger (Editors), Chronostratigraphie und Neostratotypen, Miozän der Zentralen Paratethys VII, $\mathbf{M}_{6}$ Pannonien (Slavonien und Serbien). Akadémiai Kiado, Budapest. pp. 586-615.

Papaianopol, I. and Olteanu, R., 1979. Contributions à l'étude du Pontien supérieur (Bosphorien) dans la partie oriental du Bassin Dacique. Rev. Roum. Géol. Géophys. Géogr. Géol., 23: 231-247.

Papp, A.. 1985. Paratethys. Gastropoda (Neritidae, Viviparidae, Valvatidae, Hydrobiidae, Stenothyridae, Truncatellidae, Bulimidae, Micromelaniidae. Thiaridae) und Bivalvia (Dreissenidae, Limnocardiidae, Unionidae) des Pannonien. In: A. Papp, Á. Jámbor and F. F. Steininger (Editors), Chronostratigraphie und Neostratotypen, Miozän der Zentralen Paratethys VII, $M_{6}$ Pannonien (Slavonien und Serbien). Akadémiai Kiadó, Budapest, pp. 276-339.

Papp, A., Jámbor Á. and Steininger, F. F. (Editors), 1985. Chronostratigraphie und Neostratotypen, Miozän der Zentralen Paratethys VII, $\mathbf{M}_{6}$ Pannonien (Slavonien und Serbien). Akadémiai Kiadó, Budapest, $636 \mathrm{pp}$

Pécsi, M., Márton, P., Schweitzer, F. and Hahn, G., 1985. The absolute chronology of the Plio-Pleistocene alluvial sequence overlying the pediment of the Matra Mountains. In: $M$. Kretzoi and M. Pécsi (Editors), Problems of Neogene and Quaternary. Akadémiai Kiadó, Budapest, pp. 109-114.

Planderová, E., 1972. Pliocene sporomorphs from the West Carpathian mountains and their stratigraphic interpretation. Geol. Pr. Správy, 59: 209-283.

Pogácsás, G., 1985. Seismic stratigraphic features of Neogene sediments in the Pannonian basin. Geophys. Trans., 30: $373-410$

Pogácsás, G., 1987. Seismic stratigraphy as a tool for chronostratigraphy: Pannonian basin. Ann. Inst. Geol. Publ. Hung., 70: 55-63.

Pogácsás, G. and Révész, 1.. 1987. Seismic stratigraphy and sedimentological analysis of Neogene delta features in the Pannonian basin. Ann. Inst. Geol. Publ. Hung., 70: 267-273.

Póka, T., 1982. Chemical evolution of the Inner Carpathian Neogene and Quaternary magmatism and the structural formation of the Carpathian basins. In: Evolution of Extensional Basins within Regions of Compression, with Emphasis on the Intra-Carpathians. Workshop/Discussion Meet.. Veszprém, 1982. Eötvös Univ., Budapest. pp. 46-48. Rabeder, G., 1985. Die Säugetiere des Pannonien. In: A. Papp. Á. Jámbor and F. F. Steininger (Editors), Chronostrat: graphie und Neostratotypen, Miozän der Zentralen Paratethys VII, $M_{6}$ Pannonien (Slavonien und Serbien). Akadémiai Kiadó, Budapest, pp. 440-463. 
Radócz, G., 1985. The history of the discovery and mining of Neogene coal deposits in Hungary. In: J. Hála (Editor), Neogene Mineral Resources in the Carpathian Basin. Historical Studies on Their Utilization. Hung. Geol. Surv., Budapest, pp. 215-257.

Rónai, A., 1978. Caractère hydrogéologique essentiel de la Grande Plaine hongroise. In: A. Rónai (Editor), Hydrogeology of Great Sedimentary Basins. Ann. Inst. Geol. Publ. Hung., 59: 462-482.

Royden, L. and Horváth, F. (Editors), 1988. The Pannonian Basin: A Study in Basin Evolution. Am. Assoc. Pet. Geol. Mem., 45, 394 pp.

Royden, L., Horváth, F and Rumpler, J., 1983. Evolution of the Pannonian Basin system. 1. Tectonics. Tectonics, 2: 63-90.

Rögl, F. and Steininger, F, F., 1983. Vom Zerfall der Tethys zu Mediterran und Paratethys. Die neogene Paläogeographie und Palinspastik des zirkum-mediterranen Raumes. Ann. Naturhist. Mus. Wien, 1981, 85 A: 135-163.

Rögl, F, and Steininger, F. F., 1984. Neogene Paratethys, Mediterranean and Indo-Pacific Seaways. In: P. J. Brenchley (Editor), Fossils and Climate. Wiley, Chichester, 11: 171-200.

Rumpler, J. and Horváth, F., 1988. Some representative seismic reflection lines from the Pannonian Basin and their structural interpretation. In: L. Royden and F. Horváth (Editors), The Pannonian Basin: A Study in Basin Evolution. Am. Assoc. Pet. Geol. Mem., 45: 153-169.

Sajgó, C., 1980. Hydrocarbon generation in a super-thick Neogene sequence in South-east Hungary. A study of the extractable organic matter. In: A. G. Douglas and J. R. Maxwell (Editors), Advances in Organic Geochemistry. Pergamon, Oxford, pp. 103-113.

Sajgó, C., Horváth, Z. A. and Lefler, J., 1988. An organic maturation study of the Hód-I borehole (Pannonian basin). In: L. Royden and F. Horváth (Editors), The Pannonian Basin: A Study in Basin Evolution. Am. Assoc. Pet. Geol. Mem., 45: 297-309.

Schreiber, O. S., Fuchs, R. and Köváry, J., 1985. Die Silicoplacentinen-Fauna des Unteren Pannonien im Mittleren Donaubecken Österreichs und Ungarns. In: A. Papp, Á. Jámbor and F. F. Steininger (Editors), Chronostratigraphie und Neostratotypen, Miozän der Zentralen Paratethys VII, $\mathrm{M}_{6}$ Pannonien (Slavonien und Serbien). Akadémiai Kiadó, Budapest, pp. 464-481.

Solti, G., 1985a. Prospection and utilization of alginite and oil shale in Hungary. In: J. Hála (Editor), Neogene Mineral Resources in the Carpathian Basin. Historical Studies on Their Utilization. Hung. Geol. Surv., Budapest, pp. 503-517.

Solti, G., 1985b. Agricultural utilization of Neogene mineral raw materials in Hungary. In: J. Hála (Editor), Neogene Mineral Resources in the Carpathian Basin. Historical Studies on Their Utilization. Hung. Geol. Surv., Budapest, pp. 519-530.

Stadnikoff, G., 1958. Ein chemisches Verfahren zur Feststellung der Ablagerungsbedingungen von Tonen und toniger Gesteinen. Glückauf, 94: 59-62.

Steininger, F. F. and Rögl, F., 1985. Die Paläogeographie der Zentralen Paratethys in Pannonien. In: A. Papp, Á. Jámbor and F. F. Steininger (Editors), Chronostratigraphie und Neostratotypen, Miozän der Zentralen Paratethys VII, $\mathbf{M}_{6}$ Pannonien (Slavonien und Serbien). Akadémiai Kiadó, Budapest, pp. 46-50.

Süto-Szentai, M., 1982. Szerves vázú mikroplankton-biozónák a Közép-Dunátúl pannóniai rétegösszletében. Annu. Rep. Hung. Geol. Inst., 1980: 309-344 (in Hungarian, with English abstract).

Süto-Szentai, M., 1985. Die Verbreitung organischer Mikroplankton-Vergesellschaftungen in den pannonischen Schichten Ungarns. In: A. Papp, Á. Jámbor and F. F. Steininger (Editors), Chronostratigraphie und Neostratotypen, Miozän der Zentralen Paratethys VII, $\mathbf{M}_{6}$ Pannonien (Slavonien und Serbien). Akadémiai Kiadó, Budapest, pp. 516-533.

Thamó-Bozsó, E., 1985. A fehérvárcsurgói kvarchomok telep ásvány-közettani vizsgálatának eredményei. Ann. Rep. Hung. Geol. Inst., 1983: 75-80 (in Hungarian, with English abstract).

Thenius, E., 1982. Zur Paläoklimatologie des Pannon (Jungmiozän) in Niederösterreich. Neues Jahrb. Geol. Paläontol. Monatsh., 1982: 692-704.

Vass, D., Repčok, I., Balogh, K. and Halmai, J., 1987. Revísed radiometric time-scale for the Central Paratethyan Neogene. Ann. Inst. Geol. Publ. Hung., 70: 423-434. 